\title{
BIOMETRIE JAKO ZÁKLAD SOUČASNÉ I BUDOUCÍ IDENTIFIKACE A AUTENTIZACE
}

\section{Pavel Pavlík}

IX: 213-458, 2007

ISSN 1212-4117

Jihočeská univerzita v Českých Budějovicích, Zdravotně sociální fakulta, katedra informačních systémů

Ještě před několika roky byly termín biometrie a biometrický systém pro většinu osob neznámé. Systémy pro skenování otisků prstů či oční duhovky jsme mohli vidět pouze ve sci-fi filmech. Postupem času si tento pojem našel cestu do podvědomí lidí a řada $\mathrm{z}$ nich se již $\mathrm{s}$ těmito biometrickými systémy reálně setkává denně. Co vlastně přesně biometrie je a jaké je její využití v současnosti, ale hlavně v brzké budoucnosti?

Biometrie je věda, která používá ke zjištění totožnosti nebo k ověření zadané identity osob jejich unikátních charakteristických rysů. Podle použitých charakteristických rysů můžeme biometrii dále rozdělit na biometrii tělesnou (fyziologickou) a biometrii chování. Do statické anatomické biometrie patří: otisk prstu, obličej, termogram obličeje, duhovka oka, sítnice oka, geometrie ruky, termogram ruky, tvar ucha, tělesný pach, struktura nehtu, forenzní DNA, dentální obraz. Do dynamické biometrie chování se řadí: hlas, gestikulace obličeje, dynamika podpisu, stisku kláves a chůze.

Každá biometrická vlastnost vykazuje různou rozlišovací sílu, mluvíme o tzv. biometrické entropii. Ta definuje, jak velkou populaci jsme na základě dané biometrické vlastnosti schopni rozlišit. Tato rozlišovací síla odpovídá množství informace, jež jsme schopni v dané biometrické vlastnosti nalézt. Např́klad teoretická rozlišovací schopnost otisku prstů je v rozmezí $1,4 \times 10^{73}$ $-6,6 \times 10^{2430}$ při současném stavu světové populace. Reálná biometrická entropie otisku prstu však klesá na hodnoty $5,3 \times 10^{36}-1,9 \times 10^{53}$, což stále bohatě postačuje. Dalším biometrickým prvkem může být duhovka oka s rozlišovací schopností 3,2x10616.

Za nejspolehlivější biometrickou veličinu můžeme považovat DNA, za nejméně pak hlas. Dynamickou biometrii ovlivňuje řada faktorů, např́klad fyzický a psychický stav osoby. Proto u biometrických vlastností definujeme následující kritéria: univerzalita (každá osoba musí tuto vlastnost mít); jedinečnost (žádné dvě osoby nesmí mít shodnou vlastnost); konstantnost (vlastnost zůstává s časem nezměněna); získatelnost (vlastnost je kvantitativně měřitelná); výkonnost (vlastnost se nesmí změnit a ani zestárnout); akceptace (ochota lidí pro nasnímání dané vlastnosti); bezpečnost (obtížné vytvoření falzifikátu dané vlastnosti); finance (cenové náklady na poř́izení systému). Tabulka č. 1 uvádí kritéria vybraných biometrických prvků.

Tab. č. 1 Kritéria vybraných biometrických prvků (Drahanský, 2007)

\begin{tabular}{|c|c|c|c|c|c|c|c|c|}
\hline 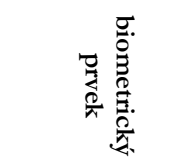 & 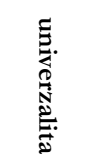 & 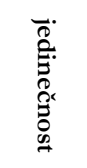 & 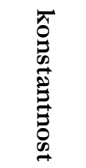 & $\begin{array}{l}N \\
\frac{N}{0} \\
\frac{0}{0} \\
\frac{0}{0} \\
\frac{0}{0} \\
0 \\
0 \\
0\end{array}$ & 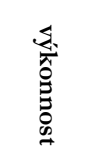 & 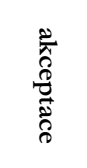 & 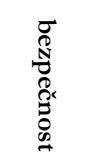 & 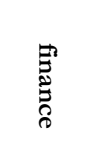 \\
\hline obličej & vysoká & nízká & střední & vysoká & nízká & vysoká & nízká & nízké \\
\hline otisk prstu & střední & vysoká & vysoká & střední & vysoká & střední & vysoká & nízké \\
\hline geometrie ruky & střední & střední & střední & vysoká & stř̌ední & střední & střední & střední \\
\hline žily ruky & střední & střední & střední & střední & střední & střední & vysoká & střední \\
\hline duhovka & vysoká & vysoká & vysoká & střední & vysoká & nízká & vysoká & vysoké \\
\hline sítnice & vysoká & vysoká & střední & nízká & vysoká & nízká & vysoká & vysoké \\
\hline podpis & nízká & nízká & nízká & vysoká & nízká & vysoká & nízká & nízké \\
\hline hlas & střední & nízká & nízká & střední & nízká & vysoká & nízká & nízké \\
\hline termogram & vysoká & vysoká & nízká & vysoká & střední & vysoká & vysoká & vysoké \\
\hline
\end{tabular}


Biometrické vlastnosti snímají, zpracovávají a vyhodnocují elektronické biometrické systémy. Obecný biometrický systém se skládá z registračního a identifikačního (verifikačního) modulu. Registrační modul pořizuje jednotlivé vzorové biometrické informace daného uživatele, ukládá je do databáze a vytváŕí novou elektronickou identitu uživatele, která je spojená s identitou fyzickou. Identifikační (verifikačnî) modul se využívá každodenně při ověřování (verifikaci) uživatelovy biometrické vlastnosti. Uživatel poskytne modulu svůj biometrický prvek, např. nasnímáním, a ten porovná aktuálně nasnímaný biometrický vzorek se vzorem, který je uveden v databázi u záznamu daného uživatele.

Biometrické systémy můžeme rozdělit na prrístupové biometrické systémy a forenzní biometrické systémy. I když tyto dva systémy pracují skoro shodně, liší se podle využití. Př́stupové systémy mají úkol výhradně verifikační a poskytují př́stupová práva $\mathrm{k}$ různým objektům (napr. vstup do prostoru s omezeným prŕstupem - nemocnice, úrady, soudy, banky; přihlášení uživatele $\mathrm{k}$ počítači či k počítačové síti). Forenzní biometrické systémy se využívají k zjištění identity/totožnosti osob a můžeme je najít např. v policejních databázích (DNA, otisky prstů, dentální informace, jizvy).

Obr. č. 1 biometrická čtečka snímající trojrozměrně geometrii ruky

Obr. č. 2 biometrický systém k optickému snímání duhovky (Panasonic BM-ET200)

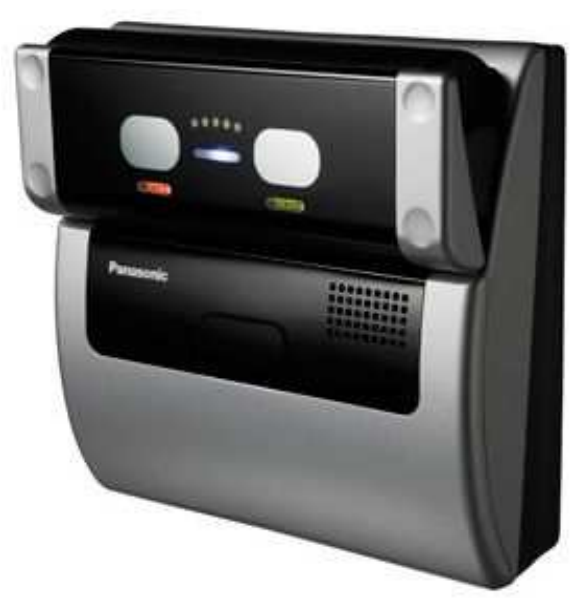

V současnosti se většinou využívá vyhodnocení pouze jedné biometrické vlastnosti, mluvíme o tzv. unimodálních biometrických systémech. Budoucnost je ale založena na multimodálních biometrických systémech, které pro rozhodování a vyhodnocování budou používat kombinaci dvou a více biometrických vlastností současně (např. otisk prstu a skenování duhovky). $S$ nasazením těchto systémů se dále snižuje možnost falzifikace a prolomení systému.

U biometrických systémů definujeme spolehlivost rozpoznání. Po naskenování biometrického prvku senzorem se vstupní data upravují a vylepšují (nap̌r. změna kontrastu, jasu, odfiltrování šumu), aby následně mohla být již „čistá" normovaná odeslána do uživatelské data- báze k porovnání a vyhodnocení. Výsledkem porovnání aktuálně nasnímaného biometrického prvku s uloženým vzorem v databázi je tzv. skóre porovnání, které se uvádí v procentech ( $0 \%$ - absolutně rozdílné vzorky; $100 \%$ absolutně shodné vzorky). Dalším velmi důležitým parametrem biometrického systému je hranice (práh) přijetí nebo odmítnutí vzorku udávaná též v procentech. Ta stanovuje, do jaké hodnoty bude vzorek odmítnut a nad jakou hodnotu príijat.

Spolehlivost biometrických systémů určuje porovnávací proces (matching) mezi referenčními a aktuálními údaji. Chybovost výsledku porovnávání je měŕítkem přesnosti dané metody. Chybovost/spolehlivost systému popisují dva 
parametry:

False rejection rate (FRR, míra chybného odmítnutî) popisuje podíl osob, které byly identifikačním přistrojem odmítnuty, ačkoli odmítnuty být neměly, k celkovému počtu osob, které byly prrístrojem prrijaty. Udává pravděpodobnost, s jakou nebude oprávněný jedinec autorizován.

False acceptance rate (FAR, míra chybného přijetî) popisuje podíl osob, které byly identifikačním prŕistrojem přijaty, ale přijaty být ve skutečnosti neměly, k celkovému počtu osob, které prijaty být neměly. Tato veličina je opak veličiny předchozí.

V následující tabulce č. 2 jsou uvedeny spolehlivosti nejobvyklejších typů biometrických prvků.

Tab. č. 2 Spolehlivost nejobvyklejších typů biometrických prvků (Granus, 2007)

\begin{tabular}{lccc}
\hline Biometrický prvek & FRR & FAR & Čas verifikace \\
\hline $\begin{array}{l}\text { geometrie ruky } \\
\text { (trojrozměrné snímání dlaně a prstů) } \\
\text { otisk prstu } \\
\text { (optické, kapacitní nebo termo snímá- }\end{array}$ & $0,1 \%$ & $0,1 \%$ & $1-3$ sekundy \\
$\begin{array}{l}\text { nî) } \\
\text { oko } \\
\text { (optické snímání duhovky- struktura, }\end{array}$ & $0,00066 \%$ & $0,0001 \%-$ & $0,2-1$ sekunda \\
$\begin{array}{l}\text { zabarvení) } \\
\text { obličej } \\
\text { (optické snímání tvaru lidské tváře) } \\
\text { hlas } \\
\text { (hlasová verifikace - basové a vysoké } \\
\text { tóny, vibrace hlasu, hrdelní a nosní } \\
\text { tóny) }\end{array}$ & $>1,0 \%$ & $0,0007 \% \%$ & 2 sekundy \\
\hline
\end{tabular}

Rychlý technický vývoj a zvýšené riziko narušení bezpečnosti vedly $\mathrm{k}$ trendu, že mnoho biometrických systémů pracuje tak, že kombinuje různé biometrické znaky fyzické osoby s jinými technologiemi identifikace nebo autentizace. Shromážděná biometrická data se proto většinou ještě kvůli bezpečnosti šifruji (kryptografie, hašovánî).

Biometrická data patří mezi citlivé osobní údaje, a proto podléhají zákonu č. 101/2000 Sb., o ochraně osobních údajů, a jeho pozdějším novelizacím; dále pak v rámci Evropské unie směrnici Evropského parlamentu a Rady EU 95/46/ES (z roku 1995), o ochraně fyzických osob v souvislosti se zpracováním osobních údajů a o volném pohybu těchto údajů; dodatkovému protokolu $\mathrm{k}$ Úmluvě o ochraně osob se zřetelem na automatizované zpracování osobních dat (CETS No. 181, rok 2004).

Ač se nezdá, biometrie se dnes už hojně využívá. Uved'me některé ze současných aplikací tohoto oboru:

- docházkové systémy (komerční organizace, státní instituce, banky);

- př́stupové systémy - fyzická bezpečnost (režimové pracoviště, elektrárny, výpočetní centra, letiště, nemocnice, státní instituce, trezory);

- ochrana počítačů a počítačových sítí - informační bezpečnost (př́istup do počítačů, počítačových sítí, k souborům, homebanking, podpisové vzory);

- identifikace osob (náhrada průkazů totožnosti za identifikační karty, náhrada podpisů a podpisových vzorů, cestovní pasy, zdravotní karty).

Podle nařízení Rady EU č. 2252/2004, o normách pro bezpečnostní a biometrické prvky v cestovních pasech a cestovních dokladech vydávaných členskými státy, schváleného dne 13. 12. 2004, jsou všechny členské státy EU 
povinny zavést první biometrické prvky (obličej) do nově vydávaných cestovních dokladů do konce srpna 2006 a další biometrické prvky (otisky prstů) do konce února 2008. Tyto biometrické charakteristiky budou použivány pro ověřování autenticity pasů a víz a také pro ověřování identity držitele pasu. Toto nařízení se začalo v ČR naplňovat dne 1. 9. 2006, kdy úřady obcí s rozšířenou působností zahájily vydávání nových cestovních pasů, které obsahují čip s prvním biometrickým údajem - elektronickou podobenkou obličeje.

Další zajímavou oblastí využití biometrie jsou elektronické čipové zdravotní karty. Vláda ČR se zavázala ve Státní informační a komunikační politice, $\mathrm{v}$ souladu s cíli EU, k zavádění informačních a komunikačních technologií do zdravotnictví, které jsou nezbytné pro efektivní spolupráci jednotlivých zdravotnických zařízení. Ceská republika si uložila postupovat v souladu s aktivitami a cíly v EU v oblasti e-zdravotnictví a postupně např́iklad nahrazovat současné průkazy pojištěnců zdravotních pojišt'oven čipovými kartami, které budou kompatibilní s mezinárodními pojištěneckými kartami užívanými $\mathrm{v}$ zemích EU. Pro prístup, identifikaci, autentizaci a celkovou ochranu této zdravotní čipové karty bude využíváno právě shora uvedených biometrických prvků uživatele.

A jak to v současné době vypadá s ekartami v EU? Do projektu elektronické čipové zdravotní karty EU se již aktivně zapojilo Německo, Velká Británie, Itálie, Francie, Holandsko a Dánsko. Např́klad SRN měla v plánu zavést elektronické karty do konce roku 2007. Aktuální stav je takový, že v osmi spolkových zemích probíhají zkušební testy s cca 10000 pojištěnci. Termín konce roku tedy určitě splněn nebude. Novou elektronickou čipovou zdravotní kartu občana SRN znázorňuje obrázek č. 3.

Obr. č. 3 Nová elektronická čipová zdravotní karta občana SRN

V České republice se projektu zdravotních ekaret přiblížila Všeobecná zdravotní pojišstovna se svou internetovou zdravotní knížkou IZIP (internetový prístup ke zdravotním informacím pacienta). Systém je zatím $v$ podobě virtuálního záznamu, který každý lékař provádí do jakési internetové knížky pacienta (zatím pouze klienta VZP). V současné době je v systému přes jeden milion internetových zdravotních knížek. Jak plánuje VZP, informace uložené v IZIPu budou mít $\mathrm{v}$ budoucnu podobu právě čipové karty kompatibilní s EU.

Jak je vidět, biometrie a biometrické elektronické systémy mají již dnes široké uplatnění a ještě větší využití se nabízí v budoucnosti. Je nutné si ale uvědomit, že získaná biometrická data jsou velmi citlivé osobní údaje a je potřeba s nimi zacházet podle platných zákonů a zabez- pečit je proti zneužití.

\section{LITERATURA}

DOČKAL, M.: Elektronická zdravotní karta v Německu. Praktické lékárenství, Olomouc: Solen, s. r. o., 2007. Vol. 3, no 2, s. 88.

DRAHANSKÝ, M.: Identita v nás ukrytá. Connect!, Brno: Computer Press, 2007. Vol. 12, no 4, s. 24-25.

PAVLÍK, P.: Informační systémy ve zdravotnictví. Kontakt, České Budějovice: JU ZSF, 2005. Vol. 7, no 1-2, s. $27-32$.

ŘIIHA, Z.: Elektronické pasy. Zpravodaj ÚVT MU, Brno: ÚVT MU, 2006. Vol. 17, no 1, s. 7-12.

Granus, s. r. o. [online]. 2007. Dostupné z: http:// www.granus.cz.

Panasonic ČR. [online]. 2007. Dostupné z: http:// www.panasonic.cz.

Úřad pro ochranu osobních údajů. [online]. 2007. Dostupné z: http://www.uoou.cz.

ZÁKON č. 101/2000 Sb., o ochraně osobních údajů.

Pavel Pavlík pavlik@zsf.jcu.cz 